\title{
Emulsifying and gelling properties of weakfish myofibrillar proteins as affected by squid mantle myofibrillar proteins in a model system
}

Propriedades de emulsificação e gelificação das proteínas miofibrilares de pescada conforme tratamento com as proteínas miofibrilares do manto da lula num sistema modelo

\section{Autores | Authors}

Daniela Mariel SUAREZ

Universidad Nacional de Mar Del Plata (UNMdP)

Facultad de Ciencias Agrarias Departamento Ciencia de los Alimentos Balcarce - Argentina e-mail:daniela_marielsuarez@hotmail.com

Emilio MANCA

Instituto Nacional de Investigación y Desarrollo Pesquero (INIDEP)

Departamento Tecnologia

Mar del Plata - Argentina e-mail: tecnoalim@inidep.edu.ar

Marcos CRUPKIN

Universidad Nacional de Mar Del Plata (UNMdP)

Departamento Ciencia de los Alimentos Balcarce - Argentina e-mail:mcrupkin@mdp.edu.ar

\ Maria Elida PAREDI

Universidad Nacional de Mar Del Plata (UNMdP)

Facultad de Ciencias Agrarias Comision de Investigaciones Cientificas de la Pcia de Bs As

Departamento Ciencia de los Alimentos Ruta $226 \mathrm{Km}$ 73,5, Pcia de Buenos Aires,

Balcarce - Argentina e-mail:meparedi@mdp.edu.ar

$\checkmark$ Autor Correspondente / Corresponding Author

Recebido / Received: 25/09/2013 Aprovado / Approved: 21/02/2014

Publicado / Published: mar./2014

\section{Summary}

The aim of the present work was to investigate the physicochemical, biochemical and functional characteristics of both the myofibrils (MF) and actomyosin (AM) of squid mantle (Illex argentinus) and weakfish (Cynoscion guatucupa) muscles, and evaluate the influence of the addition of myofibrilar proteins from the squid mantle on the physicochemical and functional properties of those of the weakfish. After extraction, purification and characterization of the MF and AM of both species, emulsions of each protein fraction from each muscle were formulated. Mixtures of the MF or AM of both species were also analyzed. The emulsifying properties were monitoring using the Emulsifying Activity Index (EAI) and Emulsion Stability (ES). In addition, gel pastes were formulated from the squid mantle, weakfish muscle and the mixture of both species, and the following functional properties of the gels assessed: water holding capacity, colour, textural profile analysis (TPA) (hardness, elasticity, cohesiveness, gumminess) and gel strength. The EAI values of emulsions formulated with the MF of the mantle were significantly $(p<0.05)$ higher than those formulated from those of weakfish. The incorporation of squid MF in the mixture increased the EAI values. Conversely, the highest ES values were obtained with weakfish MF, and the incorporation of MF weakfish in the mixture increased the ES values. Similar EAI and ES behaviours were observed for the AM of the corresponding species. Irrespective of the thermal treatment, the gel strength of the gelled paste of squid muscle was significantly $(p<0.05)$ lower than that of weakfish muscle and of those obtained with the different mixtures. The behaviours of the expressible moisture (EM) from the gelled pastes were similar to those of gel strength. Irrespective of the thermal treatment, the pastes formulated with a high weakfish: mantle ratio showed less water loss. The gelled pastes of squid mantle showed the highest values for whiteness (WI) and the incorporation of squid muscle protein improved the WI of the mixtures.

Key words: Muscle proteins; Thermal gelation; Functional properties; Squid; Weakfish. 
Resumo

O objetivo do presente trabalho foi investigar as características físicoquímicas, bioquímicas e funcionais de miofibrilas (MF) e actomiosina (AM) provenientes do músculo do manto de lula (Illex argentinus) e da pescada (Cynoscion guatucupa) e avaliar a influência da adição de proteínas miofibrilares do manto de lula sobre as propriedades físico-químicas e funcionais da pescada. Depois da extração, purificação e caracterização das MF e AM de ambas as espécies, foram formuladas emulsões de cada fração de proteína para cada um dos músculos. Também foi analisada a mistura de MF ou AM de ambas as espécies. Foram monitoradas as propriedades emulsificantes a partir do índice da atividade de emulsificação (IAE) e da estabilidade da emulsão (EE). Além disso, foram formuladas pastas de gel a partir do manto de lula, do músculo de pescada e da mistura de ambas as espécies e foram avaliadas as seguintes propriedades funcionais dos géis: capacidade de retenção de água, cor, análise do perfil de textura (APT) (dureza, elasticidade, coesividade, gomosidade) e a resistência do gel. Os valores do IAE para as emulsões formuladas com a MF do manto foram significativamente $(p<0,05)$ maiores do que as formuladas a partir da pescada. A incorporação de MF de lula na mistura aumentou os valores de IAE. Reciprocamente, foram obtidos maiores valores de EE com MF de pescada e a incorporação do MF de pescada na mistura aumentou os valores de EE. Um comportamento semelhante de IAE e EE foram observados na AM das espécies correspondentes. Independentemente do tratamento térmico, a força do gel da pasta gelificada do músculo de lula foi significativamente $(p<0,05)$ menor do que aquela do músculo de pescada e dos obtidos com as diferentes misturas. $O$ comportamento da umidade expressável (UE) da pasta gelificada foi semelhante ao de resistência do gel. Independentemente do tratamento térmico, as pastas formuladas com maior proporção de pescada:manto mostraram uma perda de água inferior. As pastas gelificadas de manto de lula apresentaram valores maiores de brancura (IB) e a incorporação da proteína muscular de lula melhorou o IB da mistura.

Palavras-chave: Proteínas musculares; Gelificação térmica; Propriedades funcionais; Lula; Pescada. 
Emulsifying and gelling properties of weakfish myofibrillar proteins as affected by squid mantle myofibrillar proteins in a model system

SUAREZ, D. M. et al.

\section{Introduction}

The squid (Illex argentinus) is one of the most important cephalopod species in the marine littoral of Argentina, due to the number of captures and the size of the specimens The cephalopods constitute an abundant natural resource of proteins, and are used as food for human consumption worldwide (GÓMEZ-GUILLÉN et al., 2003). The flesh of these species offers many advantages over the flesh of other sea species, such as high-post processing yield, very low fat content, bland flavour and light colour. Due to the flesh characteristics, it can be used for the elaboration of analogue seafood products and for other gels or restructured products (GÓMEZGUILLÉN et al., 2002). Knowledge of the characteristics of the squid mantle myofibrillar proteins is very important for the elaboration of these products, since they are responsible for the functional properties such as gel forming ability, emulsifying ability and water holding capacity (XIONG, 1997). Little information is available on the biochemical and physicochemical properties of the actomyosin and other myofibrillar proteins from the various marine molluscs found along the Argentinean marine littoral (PAREDI et al., 1990; PAREDI, 1994; PAREDI et al., 2006).

Cephalopods are characterized by having high levels of proteolytic activity, and the activity of several types of proteases has been associated with changes in the functional properties of the structural proteins from the muscle of different squid species (NAGASHIMA et al., 1992; AYENSA et al., 2002). Paredi and Crupkin (1997) reported a reduction in the extractability, reduced viscosity and a reduction in $\mathrm{Mg}^{+2}$ ATPase activity in presence of $\mathrm{Ca}^{+2}$ in the actomyosin from the squid mantle (Illex argentinus) during frozen storage. Similar results were obtained when the same squid species was frozen and stored whole (PAREDI et al., 2006). Little information is available on the thermal gelation of the squid mantle (Illex argentinus) (PAREDI et al., 1999; PAREDI and MANCA, 2006, 2007) myofibrillar proteins. Other papers have reported that the proteolytic activity in the muscles of these molluscs mainly affects the heavy chain of myosin, reducing the muscle gelation ability and consequently producing low-strength gels (GÓMEZ-GUILLÉN et al., 2003). Paredi and Manca (2007) suggested the presence of metallo or serine proteases in the squid mantel paste, being metallo proteases more abundant than serine proteinases, would mask the setting ability in the absence of inhibitors. This phenomenon implies the formation of myosin nets due to cross-linking induced by endogenous transglutaminase (TGase) (TSUKAMASA et al., 1993; HEMUNG et al., 2008), and the thermal formation of non-covalent bonds and disulphide bridges (HOSSAIN et al., 1998).
Studying the functional properties of fish myofibrillar proteins is of great importance to determine and preclude the final quality of sea fish products. Several studies have found high correlation between changes in the protein solubility, apparent viscosity and emulsifying ability of different sea fish species, which were associated with modifications in their myofibrillar proteins (XIONG, 1997; RUIZ-CAPILLAS et al., 2002)

The weakfish Cynoscion guatucupa is distributed in the SW Atlantic from the coast of Rio de Janeiro, Brazil $\left(22^{\circ} 35^{\prime} \mathrm{S}\right)$ to the coast of the Chubut province in Argentina $\left(43^{\circ} \mathrm{S}\right)$ (HAIMOVICl et al., 1989; JAUREGUIZAR et al., 2006). It is a demersal fish that can live either in salty estuarine waters (salinity no lower than 20 per mil) or in marine habitats, moving towards coastal waters in the spawning season. The species is underutilized and is typically destined for the local market. Little is known about the physicochemical and functional properties of the weakfish myofibrillar proteins, but other sea fish species such as the Brazilian flatfish (BUITRAGO CARO et al., 2009), white croaker, hake (PAGANO, 2005) and flounder (PAREDI et al., 2010) have been thoroughly studied to evaluate the biochemical and functional properties of their myofibrillar proteins.

The aim of the present work was to investigate the physicochemical, biochemical and functional characteristics of the weakfish (Cynoscion guatucupa) myofibrils, and to evaluate the possible influence of incorporating squid mantle (IIlex argentinus) myofibril proteins on the functional properties of weakfish.

\section{Material and methods}

The squid specimens (IIlex argentinus) were caught on the Patagonian shelf by a research ship at latitudes of $45-52^{\circ} \mathrm{S}$ in the southwestern Atlantic Ocean. The specimens were frozen at $-30^{\circ} \mathrm{C}$ on board as whole squid in $10 \mathrm{Kg}$ blocks, and transported to the laboratory 20 days after capture $(t=0)$. After partial defrosting, the mature females (gonad stage 4-5) were eviscerated. Their mantles were separated from the fins, skinned, vacuumpacked in polyethylene bags, three mantles (average weight 450 grams) per bag, and frozen at $-30{ }^{\circ} \mathrm{C}$. The sexual maturation stage of the specimens was determined by macroscopic observation of the gonads according to Brunetti (1990).

Weakfish specimens (Cynnoscion guatucupa) were caught by commercial vessels and kept in ice (ratio $1: 1)$. They were transported to the laboratory $24 \mathrm{~h}$ after capture. The specimens were gutted in the early post rigor stage, eviscerated and filleted by hand, and the fillets analyzed. 
Emulsifying and gelling properties of weakfish myofibrillar proteins as affected by squid mantle myofibrillar proteins in a model system

SUAREZ, D. M. et al.

\subsection{Extraction and purification of myofibrils and actomyosin from the squid mantle (I/lex argentinus)}

Myofibrils (MF) and actomyosin (AM) were obtained from the mantle according to Paredi (1994) and Paredi et al. (1990), respectively, in the presence of $0.1 \mathrm{mM}$ phenylmethane sulfonyl fluoride (PMSF). The final MF pellet was suspended in 20mM Tris-maleate ( $\mathrm{pH}$ 6.8) buffer containing $0.1 \mathrm{M} \mathrm{KCl}$. The final actomyosin pellet was dissolved in 20mM Tris-maleate ( $\mathrm{pH}$ 6.8) buffer containing $0.6 \mathrm{M} \mathrm{KCl}$. All the extraction and purification steps were carried out at $2-4{ }^{\circ} \mathrm{C}$.

\subsection{Extraction and purification of actomyosin and myofibrils from weakfish (Cynnoscion guatucupa)}

Fresh fillets were chopped, $4 \mathrm{~g}$ portions homogenized and the myofibrils isolated and purified according to Pagano et al. (2001). The actomyosin was extracted according to Paredi et al. (2010). The final actomyosin pellet was dissolved in 20mM Tris-maleate buffer $(\mathrm{pH}$ 6.8) containing $0.6 \mathrm{M} \mathrm{KCl}$. All the extraction steps were carried out at $2-4{ }^{\circ} \mathrm{C}$.

\subsection{Protein determination}

The protein concentrations in the suspensions containing squid and weakfish myofibrils and actomyosin were determined according to Lowry et al. (1951), using bovine serum albumin as the standard.

\subsection{Electrophoresis in $10 \%$ polyacrylamide gels (SDS-PAGE)}

Electrophoresis was carried out in 10\% SDS-PAGE gels according to Laemmli (1970) using a Miniprotean Tetra (model $n^{\circ}$ power pack Basic) equipment. Aliquots of the mantle and weakfish myofibrils were taken and denatured in denaturing buffer $(1 \mathrm{M}$ Tris- $\mathrm{HCl}, \mathrm{pH} 6.8,10 \%$ SDS, glycerol, -mercaptoethanol, 0.05\% bromophenol blue, distilled water) 1:1 (v/v) sample/buffer ratio, with heating at $100{ }^{\circ} \mathrm{C}$ for $5 \mathrm{~min}$. Thirty microgram aliquots were loaded onto the gel to obtain a linear response for protein concentration (PAREDI et al., 1990). The electrophoresis voltage was set at $100 \mathrm{~V}$ for $1 \mathrm{~h} 20 \mathrm{~min}$.

Wide range molecular weight markers were used to determine the molecular weights of each polypeptidic band (Bio-Rad Laboratories Inc., Hercules, CA, USA), containing rabbit myosin (200 kDa), Escherichia coli -galactosidase (116.25kDa), rabbit phosphorylase b (97.4 kDa), bovine albumin (66.2 kDa), egg albumin (45 $\mathrm{kDa})$, bovine erythrocytes carbonic anhydrase (29 kDa), trypsin inhibitor (21.5kDa), Lysozyme (14.4kDa) and apronitine.
The quantitative composition of the bands was determined using the Gel-pro analyzer program, version 3.1 (Cybernetics media, Silver Springs, Maryland USA, 1998). The relative percentages of each band were calculated as follows: (study band area/ of total band areas) $\times 100$. The myosin/actin and $\mathrm{MHC}+$ MLCs/actin area ratios were calculated according to Paredi et al. (1990)

\subsection{ATPase activity determination}

The $\mathrm{Mg}^{2+} \mathrm{Ca}^{2+}$ ATPase activity of the squid mantle myofibrils was determined at $30^{\circ} \mathrm{C}$ in $30 \mathrm{mM}$ Tris-maleate (pH 7) buffer. The enzyme conditions were as follows: $0.100 \mathrm{mg} / \mathrm{ml}$ protein, $1.5 \mathrm{mM}$ ATP, $2 \mathrm{mM} \mathrm{MgCl}, 0.1 \mathrm{mM}$ $\mathrm{CaCl}_{2}$ and $60 \mathrm{mM} \mathrm{CIK}$. The samples were incubated for $1 \mathrm{~min}$ and chilled trichloroacetic acid (40\%) at a final concentration of $10 \%$ then added to stop the reaction. After centrifugation at $850 \mathrm{~g} \times 5 \mathrm{~min}$., the supernatant was collected to determine the released phosphorous according to Chen et al. (1956).

The $\mathrm{Mg}^{2+} \mathrm{Ca}^{2+}$ ATPase and $\mathrm{Mg}^{2+}($ EGTA)ATPasea ctivities of the weakfish myofibrils were determined at 35 ${ }^{\circ} \mathrm{C}$ in $30 \mathrm{mM}$ ( $\mathrm{pH} 7$ ) buffer. The specific conditions for each enzyme were: $100 \mathrm{mg} / \mathrm{ml}$ protein, $1 \mathrm{mM}$ ATP, $2 \mathrm{mM} \mathrm{MgCl}_{2}$, $0,1 \mathrm{mM} \mathrm{CaCl}$, and $60 \mathrm{mM} \mathrm{KCl}$ for the $\mathrm{Mg}^{2+} \mathrm{Ca}^{2+}$ ATPase activity and $0.100 \mathrm{mg} / \mathrm{ml}$ protein, $1.25 \mathrm{mM}$ ATP, $2 \mathrm{mM}$ $\mathrm{MgCl}_{2}, 0.5 \mathrm{mM}$ EGTA and $60 \mathrm{mM} \mathrm{KCl}$ for the $\mathrm{Mg}^{2+}($ EGTA) ATPase activity. The incubation time for both enzymes was $4 \mathrm{~min}$. The reaction was stopped by adding $40 \%$ trichloroacetic acid (cold) at a final concentration of $10 \%$, and the released phosphorous determined according to the previously procedure described. All determinations were carried out in triplicate.

\subsection{Emulsifying activity index (EAI) and stability of the emulsion (ES)}

The emulsions were prepared by homogenizing 3ml of $0.1 \%$ protein solution with $1 \mathrm{ml}$ of pure sunflower oil for 1 min using a Omni-Mixer Sorvall 17106 homogenizer with an attache at 5000rpm (Sorvall products Inc., Newton, CT, USA). The EAI and ES were determined by the Pearce and Kinsella (1978) turbidimetric method. After preparation of the emulsion, fifty (50) $\mu \mathrm{l}$ were pipetted from the bottom of the container and added to $5 \mathrm{ml}$ of $0.01 \mathrm{M}$ phosphate buffer, $\mathrm{pH} 7$ containing $0.1 \%(\mathrm{w} / \mathrm{v})$ sodium dodecyl sulphate (SDS) at $0 \mathrm{~min}$, and left for $10 \mathrm{~min}$. The absorbance was read at 500nm. The Emulsifying Activity (EAI) refers to the reading taken immediately after preparation of the emulsion (time 0). The Emulsion Stability (ES) was determined as $E E=T / T_{0}$, where $T$ and $T_{0}$ correspond to the turbidities at $10 \mathrm{~min}$ and $0 \mathrm{~min}$., respectively (XIE and HETTIARACHCHY, 1997). All the determinations were carried out in triplicate. 
Emulsifying and gelling properties of weakfish myofibrillar proteins as affected by squid mantle myofibrillar proteins in a model system

SUAREZ, D. M. et al.

Emulsions containing a mixture of the myofibrils and actomyosin from both species were obtained according to the above mentioned procedure. In these emulsions, the protein concentrations of the myofibrils and actomyosin of both species reached $1 \mathrm{mg} / \mathrm{ml}$. Two mixtures (ratios: $1: 1$ and $1: 3(\mathrm{v} / \mathrm{v}))$ were prepared (weakfish/squid ratios).

\subsection{Preparation of squid mantle and weakfish pastes and thermal gelation}

Paste gels were obtained from squid mantles according to Paredi and Manca (2006). Three or four mantles were peeled off and cut into small pieces, (300$350 \mathrm{~g}$ ), prior to homogenization in a multiprocessor. After stabilizing the temperature at $-2-0{ }^{\circ} \mathrm{C}, 3 \% \mathrm{NaCl}$ was added (physiological $\mathrm{pH}$ of 6.4). The paste obtained was sieved and placed in cylindrical plastic recipients $(3 \mathrm{~cm}$ $\times 10 \mathrm{~cm}$ ) eliminating the air for the thermal treatment. The treatment was carried out in 1 or 2 steps. In the first case, the paste was incubated in a water bath at $85^{\circ} \mathrm{C}$ for $20 \mathrm{~min}$ (temperature at the core of the cylinder of $80^{\circ} \mathrm{C}$ ). In the second case, the paste was pre-incubated at $40{ }^{\circ} \mathrm{C}$ for $1 \mathrm{~h}$ and then heated at $85^{\circ} \mathrm{C}$ for $20 \mathrm{~min}$ to favour setting (gel stabilization at low temperatures). After heating, the gelled products were immediately immersed in a mixture of water and ice for $1 \mathrm{~h}$ and stored for $12 \mathrm{~h}$ in a fridge.

The weakfish gel paste was obtained from three fresh fillets following the procedure described above. The mixed squid mantle and weakfish pastes were prepared using three samples of each species. For the paste formulations, ratios of 1:1 and 1:3 (g weakfish muscle /g squid mantle muscle) were used. The gels were obtained following the same procedure previously described for squid.

After removing the gels from the plastic recipients, they were cut into $2.5 \mathrm{~cm}$ long cylinders to determine the water holding capacity, colour, texture profile analysis and gel strength.

\subsection{Gel strength determination}

The fracture strength $(\mathrm{N})$ and deformation $(\mathrm{cm})$ of the gel pastes were determined using $2.5 \mathrm{~cm}$ long cylinders in a TA-XT2i texture analyzer (Stable Micro System, U.K.) equipped with a P/3 SMS ( $v=5 \mathrm{~mm} / \mathrm{sec})$ cylindrical plunger. The gel strength was calculated by multiplying the values for $\mathrm{N} \times \mathrm{cm}$. All the determinations were carried out in triplicate.

\subsection{Texture profile analysis}

The gel pastes were cut into cylinders $(2.5 \mathrm{~cm}$ long) and submitted to a texture analysis (TPA) using a TA-XT2i texture analyzer (Stable Micro System, U.K.). A cylindrical probe with a flat contact surface of $7.5 \mathrm{~cm}$ in diameter was used. Two compression cycles were carried out
(30\% compression at $1 \mathrm{~mm} / \mathrm{sec}$ ) with an interval of $15 \mathrm{sec}$ between cycles. The following parameters were obtained from the profiles: hardness, cohesiveness, gumminess and elasticity, calculated according to Bourne (1978). All determinations were made in triplicate.

\subsection{Colour determination}

Colour was measured with a Minolta CR300 colorimeter using the $\operatorname{CIE}\left(L^{*}, a^{*}, b^{*}\right)$ scale, which is composed of three parameters: $L^{*}$, represents the degree of lightness of the sample, and the coordinates $a^{*}$ and $b^{*}$ are, which combined represent the shade and saturation of the colour. The whiteness (WI) was calculated according to the Lanier (1992) method. All determinations were carried out in triplicate.

\subsection{Water holding capacity}

The water holding capacity was determined by measuring the expressible moisture (EM) in $4 \mathrm{~g}$ samples by centrifugation ( $150 \mathrm{~g} \times 25 \mathrm{~min}$.), according to Pietrasik and Li-Chan (2002). The EM was calculated as \% exudates released after centrifugation $/ 100 \mathrm{~g}$ of gel. All determinations were carried out in triplicate

\subsection{Statistical analysis}

The analysis of variance and Duncan's new multiple range test were applied using the Statistica/MAC (STATSOFT, 1994) statistical analysis package.

\section{Results and discussion}

\subsection{Physicochemical properties of the squid mantle and weakfish myofibrils}

In order to characterize the MF of both species, electrophoresis was carried out in $10 \%$ SDS-PAGE of the squid mantle and weakfish myofibrils at zero time (Figure 1). The relative percentages of myosin (M) and $\operatorname{actin}(A)$, and the myosin/actin $(M / A)$ ratios were also measured. The $\mathrm{Mg}^{2+}\left(\mathrm{Ca}^{2+}\right)$ ATPase activity was measured in the MF of both species, this being a measure of the myosin-actin interactions in the actomyosin complex in the presence of exogenous calcium. The $\mathrm{Mg}^{2+}(\mathrm{EGTA})$ ATPase activity in the weakfish MF, which allows one to monitor the integrity of the tropomyosin-troponin complex (Table 1), was also determined.

Polypeptide bands characteristic of the major myofibril complex, heavy myosin chain (200kDa), actin $(43 \mathrm{kDa})$, tropomyosin $(36 \mathrm{kDa})$ and light myosin chains (19-23kDa) were observed in the electrophoretic profiles of the weakfish myofibrils. A similar polypeptide band composition has been reported for the myofibrils from hake (Merluccius hubbsi Marini) (PAGANO et al., 2001) and 
Emulsifying and gelling properties of weakfish myofibrillar proteins as affected by squid mantle myofibrillar proteins in a model system

SUAREZ, D. M. et al.

Table 1. Biochemical, physicochemical and functional properties of squid mantle and weakfish myofibrils.

\begin{tabular}{|c|c|c|}
\hline Biochemical, physicochemical and functional properties & Squid & Weakfish \\
\hline $\mathrm{Mg}^{2+}\left(\mathrm{Ca}^{2+}\right)$ ATPase $(\mu \mathrm{molPi} / \mathrm{mg}$ protein.min. $)$ & $0.87 \pm 0.04$ & $0.35 \pm 0.01$ \\
\hline $\mathrm{Mg}^{2+}(\mathrm{EGTA})$ ATPase ( $\mu \mathrm{molPi} / \mathrm{mg}$ protein.min.) & ---- & $0.23 \pm 0.03$ \\
\hline Relative percentage of myosin (\%) & $44.08 \pm 1.65$ & $49.65 \pm 1.05$ \\
\hline Relative percentage of actin (\%) & $33.52 \pm 2.19$ & $28.54 \pm 2.34$ \\
\hline Ratio $\mathrm{M} / \mathrm{A}$ & $1.32 \pm 0.07$ & $1.75 \pm 0.15$ \\
\hline
\end{tabular}

Each value represents the mean $\pm S D(n=8)$

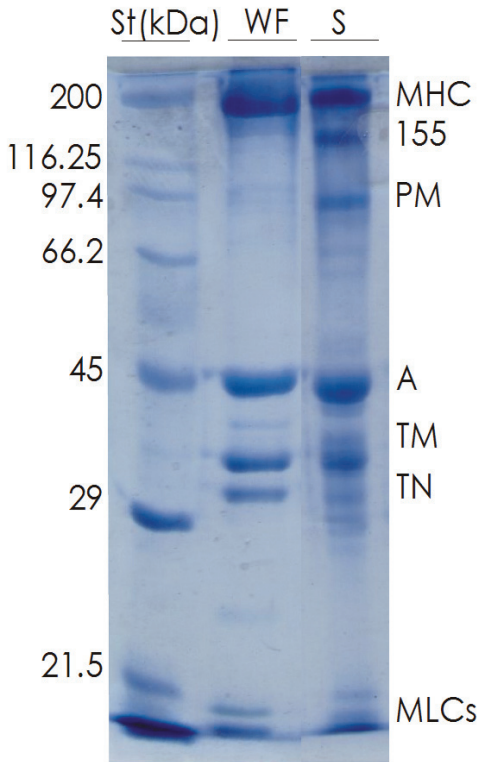

Figure 1. 10\% SDS-PAGE gels of the squid mantle and weakfish myofibrils. St: Molecular weight markers. WF: weakfish.S: squid. MHC: heavy myosin chain (200kDa); PM: paramyosin (103kDa); A: actin $(45 \mathrm{kDa}) ;$ TM: tropomyosin $(36 \mathrm{kDa}) ; \mathrm{TN}$ : troponin $(31 \mathrm{kDa}) ;$ MLCs: light myosin chains (18-20kDa).

croaker (PAGANO, 2005). Apart from the major bands, the electrophoretic profile of the mantle myofibrils showed a $155 \mathrm{kDa}$ band, probably related to proteolytic activity, and similar results were reported for the actomyosin obtained from the whole squid in two different stages of gonad reproduction (PAREDI et al., 2006; MIGNINO et al., 2008).

The values obtained for the enzymatic activity and the electrophoretic profiles obtained for both species indicated good functionality and integrity of the myofibrils.

\subsection{Functional properties of the squid mantle and weakfish}

Proteins show tensile strength (active) due to their amphiphilic nature, and therefore they can be used as emulsifying agents since they favour the formation, improve the stability and produce desirable physicochemical properties in oil-water emulsions. Due to their tendency to denature they are easily absorbed at the oil-water interface to form thin, viscoelastic

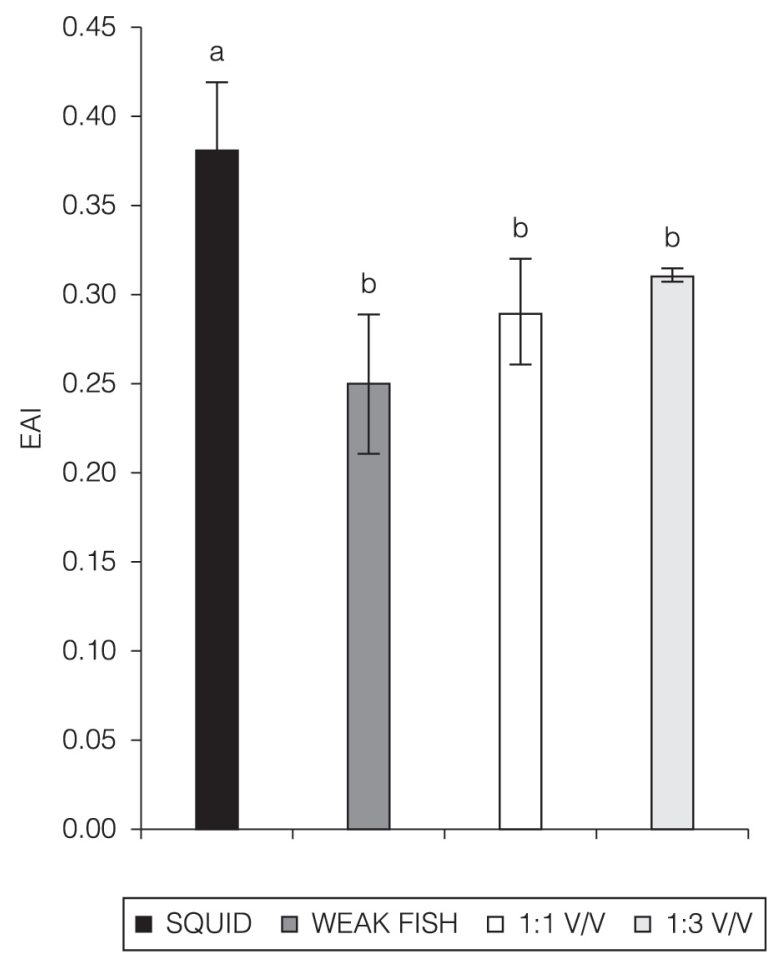

Figure 2. EAl of the myofibrils from ( $\mathbf{\square})$ squid mantle, ( $\square$ ) weakfish, mixture $(\square)$ 1:1 and $(\square)$ 1:3 (v/v). Results are expressed as the means of 12 determinations \pm SD. $(a, b)$ Different superscripts indicate significant difference $(p<0.05)$.

films, producing a decrease in the interfacial tension and delaying coalescence (McCLEMENTS, 2004). In the complex composition and structure of processed meat products, the proteins have been identified as the components that play the most important role in the water holding capacity, gelation, emulsification and consistency of the products.

Figures 2 and 3 show the values for the EAI (emulsifying activity index) and ES (emulsion stability) of the squid mantle and weakfish muscle myofibrils (MF) and the mixture of the two species.

Figure 2 shows that the EAI values for the emulsions formulated with squid mantle MF were significantly $(p<0.05)$ higher $(34.2 \%)$ than those formulated with weakfish MF. The higher EAl values obtained for the mantle, as compared to those obtained for weakfish, could be related to the proteolytic activity present in the 
Emulsifying and gelling properties of weakfish myofibrillar proteins as affected by squid mantle myofibrillar proteins in a model system

SUAREZ, D. M. et al.

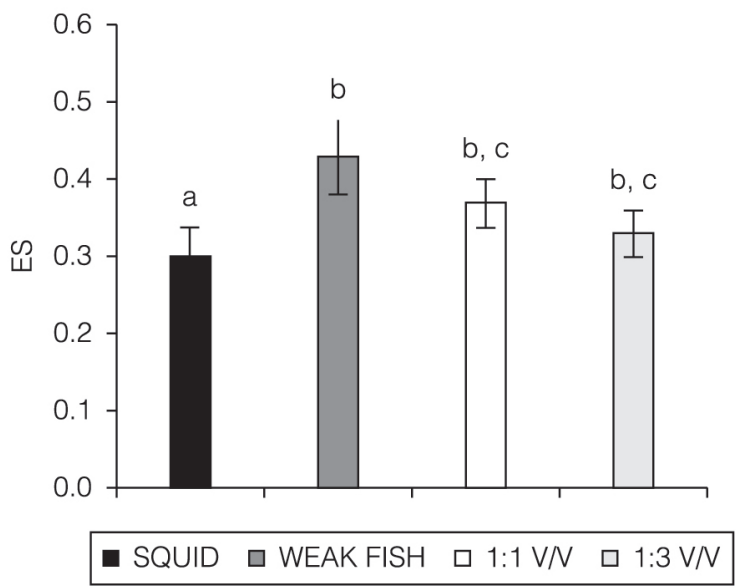

Figure 3. ES of myofibrils from ( $\square)$ squid mantle, ( $\square$ ) weak fish, mixtures $(\boldsymbol{\square}) 1: 1$ and $(\square)$ 1:3 (v/v). Results are expressed as the means of 12 determinations \pm SD. $(a, b, c)$ Different superscripts indicate significant difference $(p<0.05)$.

mantle, which has been reported to favour these functional properties (MIGNINO et al., 2008, 2013). The EAI of the mixture showed intermediate values between those from squid and weakfish. The highest EAl values obtained in the MF mixture were found when a greater proportion of squid MF was present. Tejada et al. (2003) reported that the EAI of the natural actomyosin extract of hake was high, probably due to the degree of protein denaturation, which allows for the exposure of a larger number of hydrophobic groups at the interface.

The term "emulsion stability" refers to the capacity of an emulsion to resist changes in its properties with time. An emulsion can become unstable due to a series of different types of physical and chemical processes. On the other hand as previously mentioned (Table 1), weakfish showed a higher percentage of myosin, which is the most important fat-emulsifying and water-holding protein in meat products, due to its capacity to place itself at the oil-water interface (XIONG, 2000).

The ES values were $30.2 \%$ higher for the emulsions formed with weakfish MF than for those formulated with mantle MF. The mixture with the higher proportion of weakfish MF showed higher ES values. The results observed in Figure 3 may suggest that the mixtures of both species favour this functional property.

The emulsions formulated with actomyosins from squid mantle, weakfish and the mixture of both species, showed the same behaviours as those obtained from myofibrils from the same species (data not shown), supporting the idea that the myosin is responsible for the functional properties, since actomyosin is a purified complex of myosin and actin, and myosin was always considered to play a secondary role in the functional properties (XIONG, 1997).

\subsection{Biochemical and functional properties of the gel pastes from weakfish, squid mantle and the mixture of both species}

The formation of gels involves the partial denaturation of the protein followed by an irreversible aggregation, resulting in a tri-dimensional network (LANIER et al., 2004). The characteristics of the myofibrillar proteins, the proteins mostly responsible for the functional properties, are of great importance for the elaboration of gel products (XIONG, 1997). Some cephalopod species show poor gelling capacity due to high proteolytic activity, affecting one of the major myofibrillar proteins (HURTADO et al., 1999; GÓMEZ-GUILLÉN et al., 2002, 2003), and studies with Illex argentines have revealed the presence of proteolytic activity during frozen storage (PAREDI et al., 2006; MIGNINO et al., 2008, 2013). Studies on cephalopods have reported a decrease in gel strength due to the presence of proteolytic activity that degrades the heavy myosin chain (NAGASHIMA et al., 1992; GÓMEZ-GUILLÉN et al., 2002, 2003).

Figure 4 shows the values for gel strength of the squid mantle paste, weakfish muscle and the mixture of both species with ratios of $1: 1$ and $1: 3 \mathrm{w} / \mathrm{w} / \mathrm{g}$ of weakfish muscle /g of mantle), submitted to different thermal treatments. As can be seen, the values corresponding to the mantle are significantly $(p<0.05)$ lower than those for weakfish. For the mantle paste, the gel strength was higher in the paste obtained by direct treatment, which could be due to some proteolytic activity occurring at the incubation temperature, which could mask the setting capacity of the mantle paste (PAREDI and MANCA, 2007). Other researchers have reported that the gelling characteristics of these products can be affected by modifications in the heavy myosin chain (NAGASHIMA et al., 1992; GÓMEZGUILLÉN et al., 2002, 2003) and that the rigidity of the gels formed changes with the myosin/actin ratio (PAREDI et al., 1999).

The gels obtained with the weakfish gel pastes in 2 steps showed higher gel strength values than those obtained by direct treatment, which could suggest that the weakfish has its setting capacity at a temperature of approximately $40^{\circ} \mathrm{C}$. It has been reported that during fish paste gelation, the setting has a close relationship with the formation of cross-links between the heavy myosin chain induced by endogenous transglutaminase action (TGase) (KUMAZAWA et al., 1995). Kumazawa et al. (1995) suggested that non-disulfide bonds could contribute to strengthening the gel matrix in tropical species, and that these are preferably formed during heating, possibly due to high enzyme activity and to a better orientation of the residues involved in the cross-linking reactions. Wan et al. (1995) found that the lower gel-forming capacity in salmon was primarily attributed to low TGase activity and to low contents of myosin and calcium ions as compared to 
Emulsifying and gelling properties of weakfish myofibrillar proteins as affected by squid mantle myofibrillar proteins in a model system

SUAREZ, D. M. et al.

walleye pollack. On the other hand, the TGase reactivity of the actomyosin from different species was highly different (ARAKI and SEKI, 1993).

The values for gel strength obtained for the mixtures were significantly $(p<0.05)$ higher than those obtained for the mantle paste, and lower than those obtained for the weakfish pastes (Figure 4). This could indicate a contribution by the weakfish to enhance the gel strength of the mixtures, regardless of the thermal treatment.

The texture profile analysis (TPA) is an objective method correlated to the sensory analysis of the texture. The TPA determination involves two successive compressions of the material, during which the evolution of the strength is recorded at constant velocity (BOURNE, 1978; POMERANZ and MELOAN, 1994). Table 2 shows

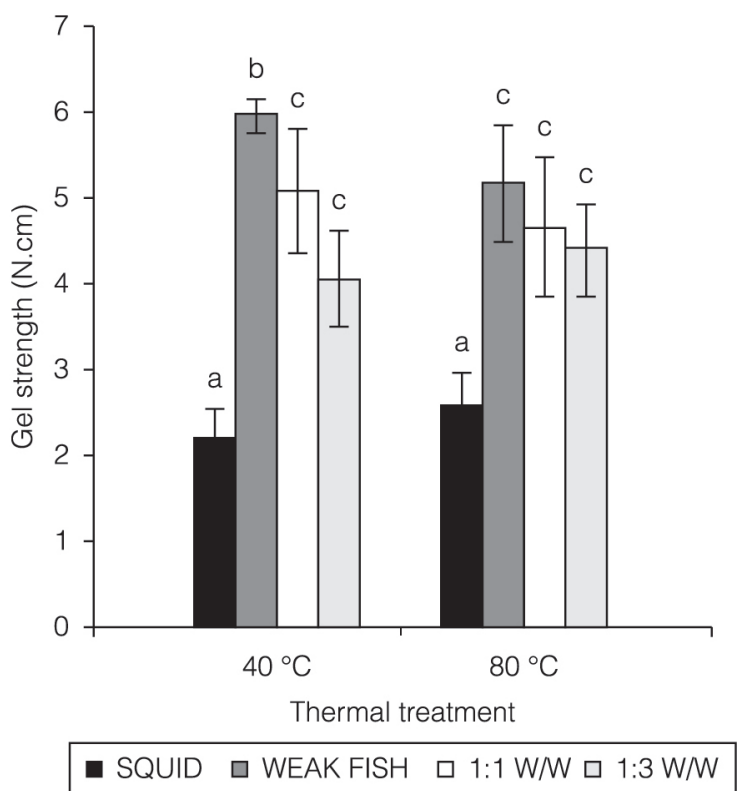

Figure 4. Gel strength of gelled paste from ( $\square$ ) squid mantle, $(\square)$ weakfish, $(\square)$ mixture ratio $1: 1,(\square)$ mixture ratio 1:3.w/w (g muscle from weakfish/g muscle from squid mantle), with different thermal treatments. Results are expressed as the means of 18 determinations $\pm S D$. $(a, b, c)$ Different superscripts indicate significant difference $(p<0.05)$. the results obtained for the parameters assessed by TPA: hardness, cohesiveness, gumminess and elasticity. The values obtained for hardness showed a similar profile to those obtained for gel strength for both thermal treatments. Cohesiveness is a property that depends on the work that must be done to stop the internal forces of the gel, which strengthens the texture (LANIER, 1992). The values for cohesiveness are related to the values for strength. In this sense, more cohesive gels have been reported to be stronger and more capable of holding water in their structure (ALVAREZ, 1993). However, in the present work the differences found between the strength of the gels formulated with squid paste, weakfish paste and the different mixtures (Figure 4) were not accompanied by significant changes in cohesiveness (Table 2). The same table shows that the lowest values for gumminess were obtained for the squid mantle. Gumminess is directly related to hardness, hence the close concordance observed between the two parameters. Elasticity is related to the height that the material recovers between the end of the first compression and the start of the second one. The values for elasticity obtained for the mixtures with ratios of $1: 1$ and $1: 3 \mathrm{w} / \mathrm{w}$ (g squid muscle /g weakfish muscle) with treatment at $85^{\circ} \mathrm{C}$, were slightly higher than those obtained from pastes elaborated with the species when studied alone. However, these differences were not significant ( $p>0.05)$ (Table 2).

Figure 5 shows the results for the expressible moisture (EM) of the gels obtained with squid paste, weakfish paste and the paste obtained with the mixture of both species with different thermal treatments. A positive relationship has been reported between the loss of water holding capacity and the proteolytic degradation of the myofibrillar proteins (CHANG LEE et al., 1989; WASSON et al., 1992). In general, there was an inverse correlation between expressible moisture and gel strength, which can be observed in Figure 5, where the weakfish gel paste showed the lowest EM and the highest gel strength, clearly seen in the gels incubated in two steps, which could suggest the presence of setting, (the process

Table 2. Hardness, cohesiveness, gumminess and springiness of the gelled pastes from squid mantle, weakfish and mixtures with ratios of $1: 1$ and $1: 3 \mathrm{w} / \mathrm{w}$ ( $\mathrm{g}$ muscle from weakfish/g muscle from squid mantle).

\begin{tabular}{ccccc} 
Sample & Hardness (N) & Cohesiveness (\%) & Gumminess (N) & Springiness (\%) \\
Squid $40{ }^{\circ} \mathrm{C}$ & $15.5 \pm 2.4^{\mathrm{a}}$ & $53.4 \pm 2.3^{\mathrm{a}}$ & $8.3 \pm 1.6^{\mathrm{a}}$ & $90.8 \pm 0.9^{\mathrm{a}}$ \\
Weakfish $40^{\circ} \mathrm{C}$ & $33.5 \pm 7.0^{\mathrm{b}}$ & $55.2 \pm 1.7^{\mathrm{a}}$ & $17.5 \pm 3.2^{\mathrm{b}}$ & $90.9 \pm 2.4^{\mathrm{a}}$ \\
$1: 1 \mathrm{~W} / \mathrm{W} 40^{\circ} \mathrm{C}$ & $28.2 \pm 8.7^{\mathrm{bc}}$ & $55.3 \pm 2.8^{\mathrm{a}}$ & $15.9 \pm 3.3^{\mathrm{b}}$ & $90.6 \pm 1.2^{\mathrm{a}}$ \\
$1: 3$ W/W $40^{\circ} \mathrm{C}$ & $25.2 \pm 8.6^{\mathrm{abc}}$ & $54.0 \pm 1.7^{\mathrm{a}}$ & $10.4 \pm 0.9^{\mathrm{a}}$ & $92.4 \pm 2.5^{\mathrm{a}}$ \\
Squid $80^{\circ} \mathrm{C}$ & $4.9 \pm 3.2^{\mathrm{a}}$ & $54.0 \pm 2.3^{\mathrm{a}}$ & $8.4 \pm 1.8^{\mathrm{a}}$ & $89.0 \pm 1.3^{\mathrm{a}}$ \\
Weakfish $80^{\circ} \mathrm{C}$ & $31.9 \pm 5.6^{\mathrm{b}}$ & $54.9 \pm 1.7^{\mathrm{a}}$ & $16.1 \pm 3.1^{\mathrm{b}}$ & $89.9 \pm 1.4^{\mathrm{a}}$ \\
$1: 1$ W/W $80^{\circ} \mathrm{C}$ & $28.2 \pm 8.4^{\mathrm{bc}}$ & $55.1 \pm 3.4^{\mathrm{a}}$ & $14.8 \pm 3.4^{\mathrm{b}}$ & $91.3 \pm 0.6^{\mathrm{a}}$ \\
$1: 3$ W/W $80^{\circ} \mathrm{C}$ & $22.3 \pm 4.5^{\mathrm{ac}}$ & $52.8 \pm 2.5^{\mathrm{a}}$ & $10.9 \pm 1.6^{\mathrm{a}}$ & $91.5 \pm 2.5^{\mathrm{a}}$ \\
\hline
\end{tabular}

Results are expressed as the means of 18 determinations \pm SD. ${ }^{(a, b, c)}$ Different superscripts within each column indicate significant difference $(p<0.05)$. 
Emulsifying and gelling properties of weakfish myofibrillar proteins as affected by squid mantle myofibrillar proteins in a model system

SUAREZ, D. M. et al.

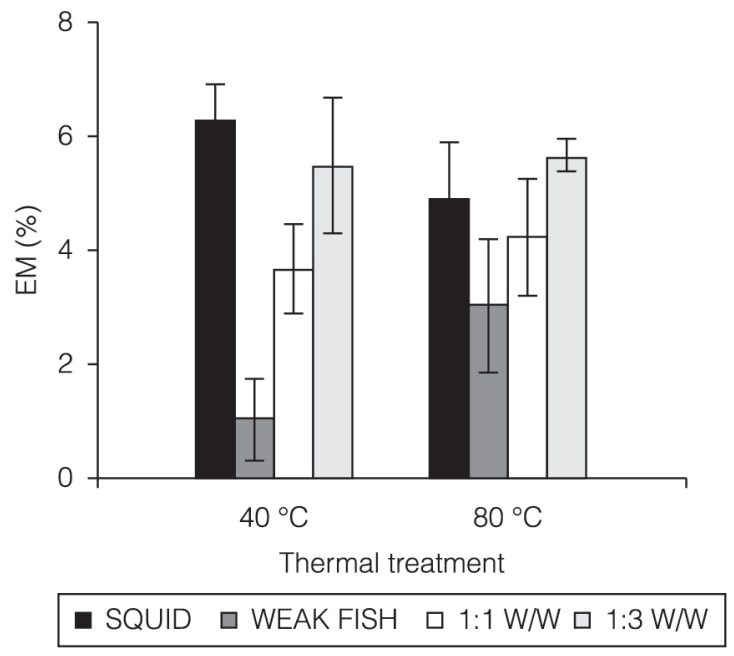

Figure 5. EM of gelled paste from ( $\square$ ) squid mantle, $(\square)$ weakfish and mixtureswith ratiosof $(\square)$ 1:1 and $(\square)$ 1:3 w/w (g muscle from weakfish/g muscle from squid mantle) with different thermal treatments. Results are expressed as the means of 18 determinations $\pm \mathrm{SD}$

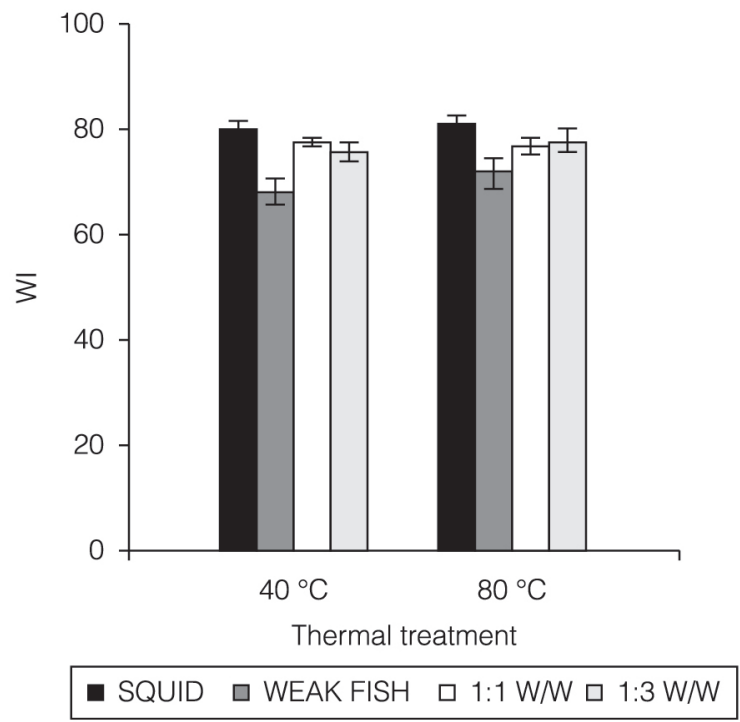

Figure 6 . WI of gelled paste from ( $\square$ ) squid mantle, ( $\square$ ) weakfish and mixtures with ratios of $(\square)$ 1:1and $(\square)$ 1:3w/w (g muscle from weak fish/g muscle from squid mantle), with different thermal treatments. Results are expressed as the means of 18 determinations $\pm \mathrm{SD}$.

of gel stabilization at low temperatures) (OKADA, 1992). According to Niwa (1992), during this process disulfidelike or hydrophobic bonds are slowly formed between the molecules of dispersed proteins, forming a reticular net homogenously dispersed, where water is confined. In the case of the squid mantle gel paste, the water loss was higher due to proteolytic degradation, which masks the setting capacity. Figure 5 also shows a great influence of the mantle proteins on the EMof the mixtures.
Figure 6 shows the results obtained for the whiteness index (WI) with the different gels obtained with both thermal treatments. The surimi is considered acceptable if the $\mathrm{WI}$ values are equal or higher than 75 (LANIER, 1992). The values observed for the weakfish gel paste were lower than the acceptable value, due to the parameter $L^{*}$, related to luminosity of the sample. This could be due to the myoglobin content of the weakfish, which produces metamyoglobin (responsible for the brown colour of gels) when oxidation occurring during heating produces metamyoglobin.

The whiteness values were (WI) significantly $(p<0.05)$ higher for mantle paste gels than for weakfish gels with both treatments. Similar results for WI were reported for squid gel paste (PAREDI and MANCA, 2007; ORTIZ MIRANDA et al., 2008). The WI values obtained for the mixtures were similar to those obtained for the squid mantle, which would indicate a positive contribution of the mantle to improve the whiteness of the weakfish gel paste.

\section{Conclusions}

A synergetic effect of the proteins on the functional properties of the pastes formulated with mixtures of MF from squid mantle and weakfish was demonstrated. The MF of squid mantle improved the EAl of the weakfish pastes. The ES of the mixture was improved by weakfish MF. Irrespective of the thermal treatment, the highest gel strength values were obtained with high weakfish: mantle ratios. The expressible moisture profiles were similar to those of gel strength, with higher WI values being obtained with higher proportions of squid MF in the paste.

\section{Acknowledgments}

We thank the Comisión de Investigaciones Científicas de la Pcia de Buenos Aires and National University of Mar del Plata, Argentina for their contributions. This study was supported by grants from the National University of Mar del Plata and ANPICYT.. FONCYT 1264.

\section{References}

ALVAREZ, C. Influencia de factores físico-químicos en la formación de geles elaborados con Surimi de Sardina (Sardina pilchardus W). Madrid: Universidad Complutense, 1993.

ARAKI, H.; SEKI, N. Comparision of reactivity of transglutaminasa to various fish actomyosins. Nippon Suisan Gakkaishi, Tokio, v. 59, n. 4 , p. $711-716,1993$.

AYENSA, M. G.; MONTERO, M. P.; BORDERIAS, A. J.; HURTADO, J. L. Influence of some protease inhibitors on gelation of squid mantle. Journal of Food Science, Malden, v. 67, n. 5, p. 1636-1641, 2002. http://dx.doi.org/10.1111/j.1365-2621.2002. tb08697.x 
Emulsifying and gelling properties of weakfish myofibrillar proteins as affected by squid mantle myofibrillar proteins in a model system

SUAREZ, D. M. et al.

BOURNE, M. C. Texture profile análisis. Food Technology, Chicago, v. 32, p. 62-66, 1978.

BRUNETTI, N. E. Escala para identificación de la madurez sexual del calamar (IIlex argentinus). Revista Frente Marítimo, Montevidéu, v. 7, sec. A, p. 45-52,1990

BUITRAGO CARO, J. J.; SUÁREZ, D. M.; CRUPKIN, M.; PAREDI M. E. Caracterización y propiedades bioquímicas y fisicoquímicas de miofibrillas de músculo de pez palo (Percophis brasiliensis). In: JORNADAS NACIONALES DE CIENCIAS DEL MAR, 7., 2009, Bahia Blanca. Anais... Bahia Blanca: IBERMAR, 2009. CD-ROM.

CHANG LEE, M. V.; PACHECO, R.; AGUILAR, D. L.; CRAWFORD, L.; LAMPILA, L. E. Proteolytic activity of surimi from Pacific withing (Merluccius products) and effects of various protein additives on gel strength. Journal of Food Science, Chicago, v. 55, n. 5 , p. $83-86,1989$.

CHEN, P. S.; TORIBARA, T. Y.; WARNER, H.; Microdetermination of phosphorus. Analytical Chemistry, Washington, v. 28, n. 11, p. 1756-1758, 1956. http://dx.doi.org/10.1021/ac60119a033

GÓMEZ-GUILLÉN, M. C.; HURTADO, J. L.; MONTERO, P. Autolysis and protease inhibition effects on dynamic viscoelastic properties during termal gelation of squid muscle. Journal of Food Science, Malden, v. 67, n. 7, p. 2491-2496, 2002. http:// dx.doi.org/10.1111/j.1365-2621.2002.tb08764.x

GÓMEZ-GUILLÉN, M.; MARTINEZ-ALVAREZ, O.; MONTERO, $P$. Functional and thermal gelation properties of squid mantle protein affected by chilled and frozen storage. Journal of Food Science, Malden, v. 68, n. 6, p. 1962-1965, 2003. http://dx.doi. org/10.1111/j.1365-2621.2003.tb07002.x

HAIMOVICI, M.; PEREIRA, S. D.; VIEIRA, P. C. La pesca demersal en el sur de Brasil en el período 1975-1985. Revista Frente Marítimo, Montevidéu, v. 5, sec. A, p. 151-163, 1989.

HEMUNG, B. O.; LI-CHAN, E. C. Y.; YONGSAWATDIGUL, J. Thermal stability of fish natural actomyosin affects reactivity to cross-linking by microbial and fish transglutaminases. Food Chemistry, Barking, v. 11, n. 2, p. 439-446, 2008.

HOSSAIN, S. M. Z.; ITO, T.; KANOHAS, S.; NIWA, E. Incorporation of dansyl glutamine into muscle protein during incubation of fish flesh sol at $30^{\circ} \mathrm{C}$. Fisheries Science, New York, v. 64, n. 1 , p. 95-98, 1998.

HURTADO, J. L.; BORDERIAS, J.; MONTERO, P.; AN, H. Characterization of proteolytic activity in octopus (Octopus vulgaris) arm muscle. Journal of Food Biochemistry, New Jersey, v. 23, n. 4, p. 469-483, 1999. http://dx.doi. org/10.1111/j.1745-4514.1999.tb00031.x

JAUREguizAR, A. J.; RuARTE, C.; GuerRero, R. A. Distribution of age-classes of striped weakfish (Cynoscion guatucupa) along an esteruanine-marine gradient: Correlations with the environmental parameters. Estuarine, Coastal and
Shelf Science, New York, v. 67, n. 1-2, p. 82-92, Mar 2006. http://dx.doi.org/10.1016/j.ecss.2005.10.014

KUMAZAWA, Y.; NUMAZAWA, T.; SEGURO, K.; MOTOKI, M. Suppression of surimi gel setting by transglutaminase inhibitors. Journal of Food Science, Malden, v. 60, n. 4, p. 715-717, 1995. http://dx.doi.org/10.1111/j.1365-2621.1995.tb06213.x

LAEMMLI, U. K. Cleavage of structural proteins during the assembly of the head bacterophege, T4. Nature, London, v. 227, p. 680-685, 1970. PMid:5432063. http://dx.doi. org/10.1038/227680a0

LANIER, T. C.; CARVAJAL, P.; YONGSAWATDIGUL, J. Surimi gelation chemistry. In: PARK, J. W. (Ed.). Surimi and Surimi Seafood. 2nd ed. New York: Marcel Dekker, 2004. p. 451-470.

LANIER, T. C. Measurement of surimi composition and funcional properties. In: LANIER, T. C.; LEE, C. M. (Eds.). Surimi Technology. New York: Marcel Dekker, 1992. p. 123-166.

LOWRY, O. H.; ROSEBRUGH, N. J.; FARR, L.; RANDALL, R. J. Protein measurement with Folin phenol reagent. The Journal of Biological Chemistry, New York, v. 193, p. 265-275, 1951.

McCLEMENTS, D. J. Proteins-stabilized emulsions. Current Opinion Colloid \& Interface Science, Chicago, v. 9. p. 305-313, 2004. http://dx.doi.org/10.1016/j.cocis.2004.09.003

MIGNINO, L. A.; CRUPKIN, M.; PAREDI, M. E. Surface hydrophobicity and functional properties of myofibrillar proteins of mantle from frozen-stored squid (IIlex argentinus) caught either jigging machine or trawling. LWT- Food Science and Technology, London, v. 41, n. 4, p. 678-685, May 2008.

MIGNINO, L. A.; CRUPKIN, M.; PAREDI, M. E. Proteolytic activity in actomyosin from mantle and fin of squid (Illex argentinus) Stored at 2-4 ${ }^{\circ} \mathrm{C}$. Influence on the physicochemical and functional properties of the protein. Journal of Food Research, Toronto, v. 2, n. 2, p. 55-64, 2013.

NAGASHIMA, Y.; EBINA, H.; NAGAI, T.; TANAKA, M.; TAGUCHI, T. Proteolysis affects thermal gelation of squid mantle muscle. Journal of Food Science, Malden, v. 57, n. 4, p. 916-922, 1992. http://dx.doi.org/10.1111/j.1365-2621.1992.tb14322.x

NIWA, E. Chemistry of Surimi gelation. In: LANIER, T. C.; LEE, C. M. (Eds.). Surimi Technology. New York: Marcel Dekker, 1992. p. 389-427.

OKADA, M. History of surimi technology in Japan. In: LANIER, T. C.; LEE, C. M. (Eds.). Surimi Technology. New York: Marcel Dekker, 1992. p. 3-41.

ORTIZ MIRANDA G. S.; MANCA, E.; PAREDI, M.E. Gelación térmica de manto y aleta de calamar (Illex argentinus). In: CONGRESO BRASILERO DE CIENCIA Y TECNOLOGÍA DE ALIMENTOS, 21., SEMINARIO LATINO AMERICANO Y DEL CARIBE DE CIENCIA Y TECNOLOGÍA DE ALIMENTOS, 15., 2008, Belo Horizonte. Actas... Belo Horizonte: [s.n.], 2008. CD-ROM. 
Emulsifying and gelling properties of weakfish myofibrillar proteins as affected by squid mantle myofibrillar proteins in a model system

SUAREZ, D. M. et al.

PAGANO, M. R. Propiedades Bioquímicas de Miofibrillas de Distintas Especies Pesqueras. 2005. 124 f. Tesis (Doctoral)Universidad Nacional de Mar del Plata, Mar del Plata, 2005

PAGANO, M. R.; PAREDI, M. E.; CRUPKIN, M. Influence of gonodal stage of hake (Merluccius hubbsi marini) on biochemical properties of myofibrils stored at $2-4{ }^{\circ} \mathrm{C}$. Journal of Food Science, Malden, v. 66, n. 2, p. 252-256, 2001. http:// dx.doi.org/10.1111/j.1365-2621.2001.tb11326.x

PAREDI, M. E. Propiedades Bioquímicas, Fisicoquímicas y Funcionales de las Proteínas Miofibrilares de Moluscos Bivalvos. 1994. 149 f. Tesis (Doctoral)-Universidad Nacional de Mar del Plata, Mar del Plata, 1994.

PAREDI, M. E.; CRUPKIN, M. Biochemical properties of actomyosin from frozen stored mantles of squid (Illex argentinus) at different sexual maturation stages. Journal of Agricultural and Food Chemistry, Davis, v. 45, n. 5, p. 1629-1632, 1997.

PAREDI, M. E.; DAVIDOVICH, L. A.; CRUPKIN, M. Thermally induce gelation of squid (Illex argentinus) actomyosin. Influence of sexual maturation stage. Journal of Agricultural and Food Chemistry, Davis, v. 47, n. 9, p. 3592-3595, 1999.

PAREDI, M. E.; DE VIDO DE MATTIO, N.; CRUPKIN, M. Biochemical properties of actomyosin of cold stored striated adductor muscle of Aulacomya ater ater (Molina). Journal of Food Science, Malden, v. 55, n. 6, p. 1567-1570, 1990. http:// dx.doi.org/10.1111/j.1365-2621.1990.tb03570.x

PAREDI, M. E.; MANCA, E. Gelación inducida por calor de pasta de manto de calamar (Illex argentinus). In: CONGRESO INTERNACIONAL DE CIENCIA Y TECNOLOGÍA DE ALIMENTOS, 2006, Córdoba. Anales... Córdoba: [s.n.], 2006. CD- ROM. PMid:16760131.

PAREDI, M. E.; MANCA, E. Gelación térmica de pasta de manto de calamar (Illex argentinus). Efecto de inhibidores de proteasas. In: CONGRESO ARGENTINO DE CIENCIA Y TECNOLOGÍA DE ALIMENTOS, 11., 2007, Buenos Aires. Proceedings... Buenos Aires: [s.n.], 2007. CD-ROM.

PAREDI, M. E.; PAGANO, M. R.; CRUPKIN, M. Biochemical and physicochemical properties of actomyosin and myofibrils from frozen stored flounder (Paralichthys patagonicus) fillets. Journal of Food Biochemistry, New Jersey, v. 34, n. 5, p. 983-995, 2010. http://dx.doi.org/10.1111/j.1745-4514.2010.00344.x

PAREDI, M. E.; ROLDAN, H. A.; CRUPKIN, M. Changes in myofibrillar proteins and lipids of squid (Illex argentinus) during frozen storage. Journal of Food Biochemistry, New Jersey, v. 30 , n. 5, p. 604-621, 2006. http://dx.doi.org/10.1111/j.17454514.2006.00088.x

PEARCE, K. N.; KINSELLA, J. E. Emulsifying properties of food proteins: evaluation of turbidimetric technique. Journal of Agricultural and Food Chemistry, Davis, v. 26, n. 3, p. 716-723, 1978.
PIETRASIK, Z.; LI-CHAN, E. C. Y. Binding and textural properties of beef gels as affected by protein k-carrageenan and microbial transglutaminase addition. Food Research International, Oxford, v. 35, n. 1, p. 91-98, 2002. http://dx.doi.org/10.1016/ S0963-9969(01)00123-5

POMERANZ, Y.; MELOAN, C. E. Rheology. In: POMERANZ, Y.; MELOAN, C. E. Food Analysis: Theory and practice. New York: Chapman and Hall, 1994. p. 449-487. http://dx.doi. org/10.1007/978-1-4615-6998-5_28

RUIZ-CAPILLAS, C.; MORAL, A.; MORALES, J.; MONTERO, P. The effect of frozen storage on the functional properties of the muscle volador (Illex coindetti). Food Chemistry, New York, v. 78, n. 2, p. 148-156, 2002.

STATSOFT. STATISTICS/MAC. Statistica for Macintosh. Tulsa: Sttatsoft Inc., 1994

TEJADA, M.; MOHAMED, G. F.; HUIDOBRO, A.; GARCIA, M. L. Effect of frozen storage of hake, sardine and mixed on natural actomyosin extracted in salt solutions. Journal of the Science and Food Agriculture, London, v. 83, n. 13, p. 1380-1388, 2003. http://dx.doi.org/10.1002/jsfa. 1555

TSUKAMASA, Y.; SATO, K.; SHIMIZU, Y.; IMAI, C.; SUGIYAMA, M.; MINEGISHI, Y.; KAWABATA, M. E. Epsilo-(gamma-glutamyl) lysine crosslink formation in sardine myofibril sol during setting at $25^{\circ} \mathrm{C}$. Journal of Food Science, Malden, v. 58, n. 4, p. 785-787, 1993. http://dx.doi.org/10.1111/j.1365-2621.1993.tb09358.x

WAN, J.; KIMURA, I.; SATAKE, M.; SEKI, N. Causes of inferior gel forming ability of salmon surimi paste. Fisheries Science, Tokio, v. 6, n. 4, p. 711-715, 1995.

WASSON, D. H.; REPPOND, K. D.; BABBIT, J. K.; FRENCH, J. $S$. Effects of additives on proteolityc and functional properties of arrowtooh flounder surimi. Journal Aquatic Food Product Technology, Philadelphia, v. 1, n. 3-4, p. 147-165, 1992. http:// dx.doi.org/10.1300/J030v01n03_10

XIE, Y. R.; HETTIARACHCHY, N. S. Xanthan gum effect on solubility and emulsification properties of soy protein isolate. Journal of Food Science, Malden, v. 62, n. 6, p. 1101-1104, 1997. http://dx.doi.org/10.1111/j.1365-2621.1997.tb12222.x

XIONG, Y. L. Meat processing. In: NAKAI, S.; MODLER, H. W. (Eds.). Food Proteins: Processing Applications. New York: Wiley-VCH, 2000. p. 89-145.

XIONG, Y. Protein denaturation and functionality losses. In: ERICKSON, M. C.; HUNG, Y. A. (Ed.). Quality in frozen food. New York: Champan and Hall, 1997. p. 111-140. PMid:9224635 PMCid:PMC1218534. http://dx.doi.org/10.1007/978-1-46155975-7_8 